\title{
Unemployment and labour market mismatch in the European Union Countries ${ }^{* 1}$
}

\author{
Gina Cristina Dimian ${ }^{2}$, Liviu Stelian Begu ${ }^{3}$, Josef Jablonsky ${ }^{4}$
}

\begin{abstract}
The purpose of this paper is to investigate some of the main drivers of high unemployment rates in the European Union countries starting from two sources highlighted in the economic literature: the shortfall of the aggregate demand and the increasing labour market mismatches. Our analysis is based on a panel database and focuses on two objectives: to measure the long and short-term impact of GDP growth on unemployment over recent years for different categories of labour market participants (young, older and low educated workers) and to evaluate the relationship between mismatches related to skills (educational and occupational) and unemployment. One of the main conclusions is that unemployment rates of young and low educated workers are more responsive to economic growth variations both in the long and short run, while unemployment rates of older workers show a greater capacity of adjustment. In addition, occupational mismatches seem to have a significant long-term impact on the changes in unemployment of all categories of unemployed, whereas the short run effect is rather mixed, varying across countries. One explanation is the fact that during crisis, economy's structure tends to change more rapidly than labour market and educational system can adapt.
\end{abstract}

* Received: 22-02-2017; accepted: 31-05-2017

1 The research is supported by the Czech Science Foundation, project P402/12/G097 "DYME - Dynamic Models in Economics".

2 Assistant Professor, Faculty of Economic Cybernetics, Statistics and Informatics, Bucharest Academy of Economic Studies, Piata Romana Square 6, 1st district, Bucharest, 010374 Romania. Scientific affiliation: labour market imbalances, international comparisons, regional competitiveness, panel data models. Phone: +40 2131919 00. Fax: +40 2131918 99. E-mail: gina.dimian@csie.ase.ro (correspondingauthor).

3 Full Professor, Faculty of Economic Cybernetics, Statistics and Informatics, Bucharest Academy of Economic Studies, Piata Romana Square 6, 1st district, Bucharest, 010374 Romania. Scientific affiliation: macroeconomics, economic convergence, international relationships, international statistics. Phone: +40213191900. Fax: +402131918 99.E-mail: liviu.begu@csie.ase.ro.

${ }^{4}$ Full Professor, Faculty of Informatics and Statistics, University of Economics. W. Churchill Sq. 4, 13067 Prague 3, Czech Republic. Scientific affiliation: efficiency analysis, multiple-criteria analysis, data mining methods. Phone: +4202 2409 5403. Fax: +4202 2409 5423. E-mail: jablon@vse.cz.Personalwebsite: http://webhosting.vse.cz/jablon. 
Key words: unemployment, economic growth, mismatches, panel data, dynamic econometric analysis

JEL classification: J62, J64, O4

\section{Introduction}

Even now, several years after the onset of the economic crisis, it seems that European labour market still faces one of the greatest challenges ever met resulted from its very slow recovery: the necessity to find short and long-term solutions in favour of the sustainable increasing of employment. Scientists' opinions are divided when it comes to the main sources of the current problems. One group of researchers claims that the roots of the labour market crisis can be found in the shortfall of the aggregate demand, while the other points to the increasing labour market mismatches. Of course, both of the two perspectives come up with targeted solutions - the first recommends a more dynamic monetary policy and fiscal stimulus, while the second insists on taking appropriate measures to deal with the mismatches between jobs requirements and workers' professional skills.

Thus, the roots of the persistent high unemployment rates in the United States and the European Union countries have been investigated in numerous studies. With respect to the United States, researchers' opinions converge to the conclusion that unemployment rate has remained at such high levels as a result of the general situation of the economy, unable to generate enough jobs. In addition, short-term data analysis tends not to support the idea that the slow pace of economic recovery may have been mainly due to structural problems (Elsby et al. 2011).

Regarding the European Union countries, labour market situation is somewhat different and the sources of high unemployment rates persistence after the economic crisis are more diverse. The general decline in the aggregate demand has been accompanied by the rise of the imbalances between job vacancies requirements and job seekers qualifications - known as mismatches. The analysis of the Beveridge curve, constructed for the Eurozone, also provides strong arguments in favour of this evidence - high levels of unemployment and job offers coexisting in the labour market (European Commission, 2013).

The most recent studies suggest that economic growth is the most appropriate solution both for reducing unemployment and for creating jobs (van Ours, 2015). It can significantly contribute to reducing unemployment among vulnerable workers, such as young people (Dixon et al. 2017), but it should not be seen as a universally valid recipe for all countries (Tomić, 2016).

Given that the studies carried out so far on the impact of cyclical and structural factors on unemployment have also a series of limitations (Rothstein, 2012: they rather focus 
on short-term transformations, manifested in the near term of the crisis, than on the long-run changes; the impact of structural problems could have been underappreciated, being covered or combined with the consequences of crisis on economic growth; what must not be overlooked is the fact that even prolonging labour market crisis will deepen structural problems and will create room for mismatches and working poor), the complex reality in which the labour markets of the EU countries are functioning and the long-term consequences that maintaining high levels of unemployment and widening mismatches can have at individual and national level, the present article aims at investigating some of the main drivers of unemployment, both in short and longterm, particular attention to different categories of participants in the labour market (young, older and low educated people) and the mismatches related to skills.

In these circumstances we have focused our empirical analysis on testing two hypotheses. First, we examined if there are any differences between unemployment response to economic growth fluctuations among vulnerable categories of workers (young, older, low educated) and how large the short-term response is compared with the long-term responsiveness. In keeping with our intention to test this hypothesis, a simple Okun's law model, the dynamic version, was applied to 28 EU member states over the period 1997-2015, which includes the recent crisis. In this stage, the Two Stage Least Squares (TSLS) method was preferred in order to deal with endogeneity problem and to compute the GDP growth rate consistent with a stable unemployment rate. The results showed that the youth unemployment rate is more responsive to fluctuations in economic growth even than the unemployment rate of low educated workers. Second, we investigated whether labour market mismatches (educational and occupational) have a significant impact on the unemployment rate of vulnerable workers and how they influence the responsiveness of unemployment rate to economic growth fluctuations. The Autoregressive Distributed Lag (ARDL) method has been employed taking into consideration the fact that the two variables that measure mismatches are expected to have different influence for each country and the method allows catching this influence at country level (different coefficients for each country in the short run). The results have shown that occupational mismatches have a significant impact on unemployment, but they also influence unemployment sensitivity to economic growth fluctuations in the long run.

Our contributions to the literature are twofold. First, we examine the relationship between GDP growth rate and the unemployment rate both on long and short-run, computing the rate of economic growth that could provide a stable unemployment rate for different categories of unemployed (young, older and low educated). Thus, we are looking for short and long-term responses to a lasting problem unemployment and targeted solutions for vulnerable workers.

Second, we include educational and occupational mismatch indexes in an augmented model in order to measure their short and long-term impact on 
unemployment and on its responsiveness to output growth changes. Having in mind that crisis itself may have generated structural disequilibria we pay special attention to factors like skills, because their role is very complex: at macroeconomic level they contribute to increasing productivity and international competitiveness while at individual level lead to labour market inclusion and personal wellbeing. They become more important in conditions of economic decline, when unemployment and poverty risk increase (CEDEFOP, 2016).

After the introduction and the literature review, the next section presents the data and methodology appropriate to answer paper research questions. Descriptive statistics of the labour market past and current conditions and econometric analysis are subject to section four. The results of the applied methodology are presented in section five. Section six focuses on the main conclusions.

\section{Literature review}

There is a wide range of studies that have quantified the impact of economic growth on unemployment. The most recent ones have focused on using Okun's law (Okun, 1962) for studying the particularities of this relationship, determined by the economic crisis.

A review of the versions that can be applied in order to measure this relationship and possible outcomes was proposed by Knotek (2007), who emphasized the relatively unstable nature of Okun relationship, depending on the state of the business cycle. Different versions of the Okun's Law have been applied at both country (Lee, 2000; Sögner and Stiassny, 2002; Dritsaki and Dritsakis, 2009; Tatoğlu, 2011; Cazes, Verick, Al Hussami, 2013; Huang and Yeh, 2013, Kargi, 2013; Ball et al, 2015; to name just a few) and regional level (Freeman, 2000; Apergis and Rezitis, 2003; Christopoulos, 2004; Villaverde and Maza 2009, Kangasharju, et al. 2012; Binet and Facchini 2013; Durech et al. 2014).

When the model was estimated on very large panels of countries and states, Okun's coefficients proved to be not only negative, but also significant in statistical terms (Huang and Yeh, 2013), while applied to smaller panels of countries, the Okun's law validity and the relationship significance were found to vary across countries (Tatoğlu, 2011). Applied at regional level, Okun Law has led to mixed results. In Spain, for example, there is a certain dualism, partially caused by the differences in productivity. Namely, there are certain regions with unemployment rates more sensitive to output growth than others (Villaverde and Maza, 2009). As regards France, Binet and Facchini (2013) proved that Okun's law does not hold particularly in regions with high shares of employment in the public sector. 
Okun Law has also been used to examine the relationship between unemployment and economic growth rate in times of crisis. In this respect, IMF (2010) demonstrated that during periods of recession, factors such as financial crisis, housing crisis and other sectoral shocks led to unemployment increase over the level projected by Okun's law, while during periods of recovery the above mentioned factors continued to impede employment growth.

Unemployment response to changes in economic growth during the recent crisis was much higher in countries such as Spain and the United States than in those which have taken supplementary measures to increase employment flexibility (Germany, Italy, Japan and the Netherlands). Thus, the long-term impact of the fluctuations in economic growth on unemployment rates dynamics was estimated to range between 0.5 and 0.8 for countries like UK, Finland, Sweden, Canada and Spain respectively between 0.0 and 0.2 for countries like Norway, Denmark, Greece, Japan, Switzerland and Austria in the last 20 years before the Great Recession (IMF, 2010).

Many recent studies, addressing the problem of youth and other age groups unemployment have also used Okun's law to formulate conclusions and recommendations for active policies (Bell and Blanchflower, 2011; Hutengs and Stadtmann, 2014; Zanin, 2014; IMF, 2015). Thus, the authors mentioned above draw attention to specific problems that the economic crisis has caused among young people: unemployment among them has increased more compared to other age cohorts; the consequences are expected to be long-term; structural factors add to cyclical ones as sources of current problems; even the Scandinavian countries with efficient functioning of the labour markets and performant education systems must cope with the problems of integrating young people into the labour market.

IMF (2015) shows that mainly in times of crisis, the unemployment rate among young people is more sensitive to output fluctuations and to the policies promoted by the labour market institutions than the unemployment rate among adults.

Labour market mismatches are defined, in a broader sense, as the gap between labour demand and the labour supply characteristics. They can occur at different levels: regions, sectors of activity, skills, occupations and so on. In general, these imbalances have been measured using aggregate indicators. Obadić (2006) makes a review of the indexes proposed in the literature, grouping them into three categories: indicators based on inter-sectoral disequilibria (using data on unemployment and vacancy rates at various levels of disaggregation and measuring the distance between the actual unemployment rate and an optimum rate of unemployment), indicators based on the NAIRU model (using data on the number of unemployed and the number of people employed and measuring the distance between the total unemployment rate and a minimum rate of unemployment) and indicators based on a leading region (measuring the distance between the total unemployment rate 
and the unemployment rate in the leading region). As expected, the application of these indexes at regional level in countries such as Croatia, Poland, Slovakia and the Czech Republic, has led to different results, but the trend depicted by them has been similar. Thus, structural unemployment caused by regional mismatches exists, but its size is difficult to quantify.

In another more recent paper indexes are grouped according to the authors who addressed this problem in the labour market literature (the Lilien Turbulence Index, the Jackman and Roper Indexes, the Evans Index and the Sahin et al. indexes). Applied on three time periods (pre-recession, great recession and post-recession) using data from the US, they revealed that both industrial and occupational imbalances have increased in US near the recession (Canon et al. 2013).

The results are in line with those obtained by Sahin et al. (2012), who demonstrated that over 2000-2010, in the US the increase in sectoral, occupational and educational mismatches can explain between 0.8 and 1.4 percentage points of the unemployment rate rise, while regional mismatches seem not to have a significant influence.

The same types of indexes, reviewed in the above mentioned papers, were used by European Commission (2013) to examine labour market mismatches across skills, industries and regions in the EU countries. Thus, educational mismatches have been shown to have a more consistent impact on labour markets equilibrium than sectoral mismatches. Although the latter imbalances have increased in most analysed countries with the onset of the crisis, they declined quite rapidly in the coming period, demonstrating a rather temporary nature. Regional mismatches have kept a downtrend even during recession, proving not to have a significant contribution to explaining the EU labour markets imbalances.

In the particular case of UK, using dynamic decomposition of the actual employment and a mismatch index, Smith (2012) proved that mismatches across industries accounted for almost a half of the unemployment rise during the recession. The same results were obtained by Bauer (2013) when she evaluated the impact of mismatches on the aggregate unemployment in Germany. All industry, occupation, occupation-regions mismatches proved to have a significant impact on the relations established in the labour market, except for the geographical ones.

The latter results tend to challenge other researchers' findings. Barlevy (2011) for example, demonstrates that a more significant contribution to the increase in unemployment appears to have the reluctance of companies to make hiring in times of recessions rather than that the fact that they cannot find the right workers for the jobs. In addition, long-term unemployment rate, seen as one of the main sources of maintaining high overall unemployment rate in the United States (Hornstein, 2012) could not have been directly correlated with structural imbalances, but rather with poor performance of the economic activities affecting the demand for labour (Valletta, 2013). 
Summing up the findings of the recent literature related to the problem of the unemployment rate - GDP growth rate relationship, it worth mentioning that, as expected, particularly in the European Union countries case, there are significant differences in terms of unemployment response to changes in economic growth rates, mainly in times of crisis, and each country's particularities should not be neglected in models addressed to them.

\section{Methodology and methods of analysis}

Aiming to answer two research objectives: assessing the relationship between GDP growth rate and unemployment rate in the near term of economic downturn that started in 2008 and measuring the impact of educational and occupational mismatches on unemployment rate, the present article has used two types of methods: statistical analysis, which allowed to capture country-specific responses to labour market problems raised by the crisis and econometric analysis that focused on short and long-term differences between vulnerable groups: young, older and low educated people.

In order to evaluate how strong has been the influence of real GDP growth on unemployment dynamic in the 28 EU countries around crisis, one of the wellknown model that relates the two indicators, namely Okun's Law (the dynamic version) has been used.

We started from the difference version of the Okun's Law (Smith, 2010):

$$
\Delta u r_{t}=\alpha+\beta g d p \_r{ }_{t}+\varepsilon_{t}
$$

where $u r_{t}$ represents the unemployment rate and $g d p_{-} r_{t}$ the real output growth rate.

Finding the rate of growth that keeps unemployment rate unchanged supposes to set

$$
\alpha+\beta g d p_{-} r_{t}=0 \quad g d p \_r r_{t}=-\frac{\alpha}{\beta}=g d p_{-} r^{*}
$$

Using this relation, one can find the rate of growth $\left(g d p \_r\right.$ * ) "consistent with a stable unemployment rate, or how quickly the economy would typically need to grow to maintain a given level of unemployment" (Knotek, 2007, p.75).

In addition, the model allows us to predict the long run impact of the GDP growth rate on the change in unemployment using the dynamic version of Okun's Law i.e. introducing the lagged dependent variable in the regression. In this case we have used past changes in unemployment:

$$
\Delta u r_{t}=\alpha+\beta g d p \_r_{t}+\gamma \Delta u r_{t-1}+\varepsilon_{t}
$$


where the long run impact of growth is (Smith, 2010):

$$
\theta=\frac{\beta}{1-\gamma}
$$

The pooled OLS regression model, in which all the coefficients are common for all countries, takes the following form:

$$
\begin{aligned}
& \Delta u r_{i t}=\alpha+\beta g d p_{-} r_{i t}+\gamma \Delta u r_{i, t-1}+\varepsilon_{i t} \\
& i=1, \ldots, N \text { (countries) and } t=1, \ldots, T \text { (years) }
\end{aligned}
$$

where $\alpha$ is the common constant, $u_{i t}$ unemployment rate for country $i$ at time $t, g d p_{-} r_{i t}$ the real output growth rate for country $\mathrm{i}$ at time $\mathrm{t}$ and $\varepsilon_{i t}$ is the idiosyncratic error, variable both across countries and time.

Since the model includes, among explanatory factors lagged dependent variable, the strict exogeneity assumption is violated. In this case, both Random Effects and Fixed Effects estimators would be biased and, as a consequence, an instrumental variables approach has been chosen to deal with this problem, namely Two Stage Least Square (TSLS) regression analysis.

In its general form, where $y$ is the dependent variable, $X$ a set of independent variables and $\mathrm{Z}$ the matrix of instruments, the objective function of the TSLS method is (Hurlin, 2010):

$$
\Psi(\beta)=\left(y-X \beta^{\prime}\right) Z\left(Z^{\prime} Z\right)^{-1} Z^{\prime}(y-X \beta)
$$

The coefficients calculated by TSLS are:

$$
\hat{\beta}_{T S L S}=\left(X^{\prime} Z\left(Z^{\prime} Z\right)^{-1} Z^{\prime} X\right)^{-1} X^{\prime} Z\left(Z^{\prime} Z\right)^{-1} Z^{\prime} y
$$

and the standard estimated covariance matrix of these coefficients is:

$$
\hat{\Sigma}_{T S L S}=s^{2}\left(X^{\prime} Z\left(Z^{\prime} Z\right)^{-1} Z^{\prime} X\right)^{-1}
$$

where $s^{2}$ is the estimated residual variance.

In the Two Stage Least Square (TSLS) analysis, among instrumental variables, besides time period dummies, dependent variable with lags and differenced independent variable with lags were included (see Wooldridge, 2010 for a list of available instruments).

Four regression models have been then estimated (M1 to M4): the first model with total unemployment rate as dependent variable, while the remaining three focused on the unemployment rate of the categories considered vulnerable in the labour market: the young, the elderly and low educated workers.

The second objective of the paper was to evaluate the relationship between labour market mismatches related to skills (educational and occupational) and unemployment 
rate. To achieve this objective Autoregressive Distributed Lag (ARDL) method has been used. ARDL method has the advantage that can be applied both to stationary or non-stationary series. We started from the Okun's law written as a panel data model that includes fixed effects and then it has been written in an error correction form (Huang and Yeh, 2013):

$$
\begin{aligned}
& \Delta u r_{i t}=\mu_{i}+\phi_{i} u r_{i, t-1}+\beta_{i} g d p_{i t}+\sum_{j=1}^{p-1} \lambda_{i j}^{*} \Delta u r_{i, t-j}+\sum_{j=0}^{q-1} \delta_{i j}^{*} \Delta g d p_{i, t-j}+\varepsilon_{i t}= \\
& =\mu_{i}+\phi_{i}\left(u r_{i, t-1}-\theta_{i} g d p_{i t}\right)+\sum_{j=1}^{p-1} \lambda_{i j}^{*} \Delta u r_{i, t-j}+\sum_{j=0}^{q-1} \delta_{i j}^{*} \Delta g d p_{i, t-j}+\varepsilon_{i t}
\end{aligned}
$$

where $\mu_{i}$ represents the fixed effects and $\varepsilon_{i t}$ is the idiosyncratic error, variable both across countries $(\mathrm{i}=1 \ldots \mathrm{N})$ and time $(\mathrm{t}=1 \ldots \mathrm{T})$.

The error correction coefficient is computed as: $\phi_{i}=-\left(1-\sum_{j=1}^{p} \lambda_{i j}\right)$ and measures the unemployment rate speed of adjustment towards the long run equilibrium. Its sign should be negative if we expect that the two variables (unemployment rate and GDP) to be long-term co-integrated.

The long run coefficient that estimates the equilibrium relationship between the variables is the ratio: $\theta_{i}=-\frac{\beta_{i}}{\phi_{i}}$, where $\beta_{i}=\sum_{j=0}^{q} \delta_{i j}$.

The short-run coefficients $\lambda_{i j}^{*}=-\sum_{m=j+1}^{p} \lambda_{i m}$ indicate the autoregressive coefficients of the dependent variable of lag $p$ and estimate unemployment dynamics time persistence.

$\delta_{i j}^{*}=-\sum_{m=j+1}^{q} \delta_{i m}$ are the coefficients of lag $q$ connecting the dependent and the independent variable and estimate short-term impact of GDP on unemployment.

Unemployment rate has been included in the model as dependent variable, GDP and mismatch indexes as dynamic regressors, in order to test their influence on the unemployment of various categories of unemployed (total, young, older and low educated) and at country level. All the variables have been measured in logs. 


\section{Empirical data analysis}

\subsection{Descriptive statistics}

The data used in this paper were collected from the EUROSTAT and ILOSTAT databases and refer to 7 variables: total unemployment rate, GDP growth rate, youth unemployment rate, older people unemployment rate, low educated people unemployment rate, educational mismatch index and occupational mismatch index (the description of the 7 variables can be found in Table A1). They cover a 19year period (1997-2015) and 28 member states of the European Union (including United Kingdom, still member in 2015). Uni-criteria statistical analysis is presented in the form of Box Plot and Kernel Density graphs. Mismatch indexes have been computed following the methodology presented in the studies revised in the literature review chapter.

To analyse the dynamics of the European Union labour market in the last years' conditions is a difficult task because there are a variety of ways in which countries coped with the economic downturn. Crisis significantly reduced the GDP growth rate in the European Union, from a median of about 3\% in 2007 to almost $-5 \%$ in 2009, and differences between countries have increased, reaching in 2009 more than 19 percentage points between Lithuania and Latvia, on one side and Poland, on the other side (Figure A1).

Starting with 2012, economic growth rate returned to an upward trend and disparities between countries began to decline. Thus, Kernel Density graphs show that in 2008 countries could be grouped into two categories: a smaller group with very low GDP growth rate (around $-5 \%$ ) and the largest group with a growth rate of approximately 1\%. The year 2015 shows two groups of countries in terms of economic growth rate, but this time, the group with fewer countries recorded high growth rates, between 6 and 9\% (Figure A1).

After a period (2005-2008) with a median unemployment rate of people aged 1564 in decline and small disparities between countries, the recent period has been characterized by both increasing the minimum rates of unemployment, from a rate of $2.7 \%$ in 2007 in the Netherlands, to $4.7 \%$ in 2015 in Germany, and maximum rates of unemployment: from a rate of $11.2 \%$ in 2007 in Slovakia to $25.1 \%$ in 2015 in Greece. Disparities between countries reached record values, of over 20 percentage points in 2015 (Figure A2).

The rate at which older people lost their jobs is also worrying, mainly because this group of the population is more likely than others to become long-term unemployed and even mismatched. In Greece and Cyprus, the annual growth rate of the unemployment rate of people aged between 55 and 64 exceeded $25 \%$ during 20082015 (Eurostat, 2016). 
As regards young workers, both the levels reached by unemployment and the differences between countries remained even in 2015, several years after the start of the crisis, very large: more than 40 percentage points between Germany and countries like Greece or Spain.

Another category of workforce at risk of becoming unemployed even for a long time is the population with a low level of education. Among this group, in many countries, the unemployment rate is double than total unemployment. In Slovakia, for example, in 2015, unemployment rate reached the highest value compared to other European countries (almost 38\%), while Cyprus and Greece experienced the highest annual growth rate of almost 20\% (Eurostat, 2016).

Kernel Density graphs show that, even since the year 2008 two groups of countries have begun to form in terms of unemployment, especially among vulnerable groups (the elderly and those with a low level of education). This trend has maintained and in 2015 the group of countries with unemployment rates much higher than the other came to be clearly delimitated among all categories of unemployed. A relative homogeneity seemed to emerge in terms of unemployment among people with a low level of education (Figure A2).

Educational mismatch indexes reveal a suggestive picture of how the education level of the workforce meets the requirements of the labour market. These indexes highlight the countries in which there are significant differences between the structure of working age population and the structure of employment in terms of three levels of education: basic, intermediate and advance. Italy, Malta and Spain are among the countries with the highest indexes in 2015 and on the increase compared to the year 2007. The share of this group of participants in the labour market is much higher than their share in employment. The largest increases in these indexes compared to 2007 were registered by countries such as: Portugal, United Kingdom and Luxemburg, while significant declines were noticeable in countries like: Latvia, Slovakia, Estonia and Czech Republic, among others (Table $1)$. 
Gina Cristina Dimian, Liviu Stelian Begu, Josef Jablonsky • Unemployment and labour... Zb. rad. Ekon. fak. Rij. $\cdot 2017 \cdot$ vol. $35 \cdot$ no. $1 \cdot 13-44$

Table 1: Educational mismatch indexes in the EU countries 2007-2013

- in $\%$

\begin{tabular}{|c|c|c|c|c|c|c|c|c|c|}
\hline $\begin{array}{c}\text { Countries/ } \\
\text { time }\end{array}$ & 2007 & 2008 & 2009 & 2010 & 2011 & 2012 & 2013 & 2014 & 2015 \\
\hline Belgium & 15.89 & 15.55 & 15.25 & 14.78 & 14.57 & 14.35 & 14.04 & 14.54 & 14.56 \\
\hline Bulgaria & 14.79 & 13.99 & 13.50 & 12.46 & 12.08 & 11.56 & 10.61 & 10.06 & 9.71 \\
\hline $\begin{array}{l}\text { Czech } \\
\text { Republic }\end{array}$ & 9.23 & 9.00 & 8.09 & 7.43 & 7.09 & 6.80 & 5.94 & 5.48 & 5.53 \\
\hline Denmark & 5.61 & 5.47 & 5.64 & 6.18 & 6.38 & 6.67 & 6.78 & 6.37 & 6.40 \\
\hline Germany & 6.69 & 6.25 & 5.99 & 5.81 & 4.42 & 4.28 & 4.11 & 5.27 & 5.17 \\
\hline Estonia & 6.55 & 6.65 & 6.51 & 5.89 & 5.54 & 5.28 & 4.26 & 3.69 & 3.90 \\
\hline Ireland & 9.52 & 9.57 & 10.28 & 10.59 & 10.61 & 10.77 & 10.15 & 10.30 & 10.29 \\
\hline Greece & 10.28 & 8.76 & 8.57 & 8.82 & 9.08 & 9.62 & 9.71 & 9.39 & 9.49 \\
\hline Spain & 10.45 & 10.88 & 12.10 & 12.24 & 12.29 & 13.21 & 13.35 & 11.04 & 10.66 \\
\hline France & 11.04 & 10.97 & 10.81 & 10.57 & 10.30 & 10.12 & 9.76 & 9.58 & 9.66 \\
\hline Croatia & 12.31 & 11.54 & 10.65 & 10.19 & 10.31 & 10.52 & 10.36 & 10.96 & 10.24 \\
\hline Italy & 12.94 & 13.13 & 13.47 & 13.66 & 13.55 & 13.31 & 13.35 & 13.35 & 13.27 \\
\hline Cyprus & 7.42 & 7.58 & 7.65 & 7.05 & 6.96 & 7.55 & 7.77 & 7.72 & 7.98 \\
\hline Latvia & 7.80 & 7.22 & 6.70 & 5.84 & 5.57 & 4.40 & 4.32 & 4.11 & 3.59 \\
\hline Lithuania & 11.72 & 12.05 & 11.51 & 11.00 & 10.32 & 9.81 & 8.96 & 8.14 & 7.52 \\
\hline Luxembourg & 5.13 & 5.91 & 6.14 & 6.39 & 6.93 & 6.71 & 7.00 & 8.22 & 7.36 \\
\hline Hungary & 13.18 & 12.34 & 11.96 & 11.27 & 10.66 & 9.99 & 9.32 & 11.35 & 10.38 \\
\hline Malta & 11.08 & 9.74 & 10.18 & 11.07 & 11.88 & 12.15 & 12.60 & 12.44 & 12.17 \\
\hline Netherlands & 6.35 & 6.14 & 6.23 & 6.74 & 6.65 & 6.73 & 6.51 & 6.88 & 6.82 \\
\hline Austria & 7.67 & 7.60 & 7.44 & 7.32 & 7.12 & 7.02 & 7.01 & 6.02 & 5.74 \\
\hline Poland & 9.75 & 9.61 & 8.98 & 8.50 & 8.16 & 7.67 & 7.27 & 6.91 & 6.53 \\
\hline Portugal & 2.78 & 3.26 & 4.35 & 4.80 & 5.62 & 5.98 & 6.82 & 8.00 & 8.25 \\
\hline Romania & 9.78 & 9.24 & 8.89 & 9.26 & 9.91 & 9.70 & 9.42 & 9.23 & 10.02 \\
\hline Slovenia & 6.52 & 6.68 & 6.11 & 6.03 & 6.38 & 6.44 & 6.34 & 5.75 & 5.71 \\
\hline Slovakia & 13.88 & 12.76 & 11.86 & 11.11 & 10.29 & 10.08 & 9.35 & 9.18 & 8.26 \\
\hline Finland & 10.54 & 10.66 & 10.70 & 10.51 & 10.24 & 10.15 & 9.77 & 9.60 & 9.51 \\
\hline Sweden & 6.19 & 6.33 & 6.09 & 5.98 & 5.86 & 5.76 & 5.58 & 6.20 & 6.00 \\
\hline $\begin{array}{l}\text { United } \\
\text { Kingdom }\end{array}$ & 1.89 & 3.26 & 2.82 & 2.94 & 2.94 & 3.13 & 3.42 & 3.51 & 3.47 \\
\hline
\end{tabular}

Source: EUROSTAT, 2014; Authors' calculation

The indexes reflecting occupational mismatch in the European Union countries showed that the most affected group was that of elementary occupations.

In 2015, for example, indexes ranged from 54\% in Luxembourg to $106 \%$ in Spain. Their evolution over time since 2007 shows a relative stability, no country has experienced dramatic changes (Table 2). 
Gina Cristina Dimian, Liviu Stelian Begu, Josef Jablonsky • Unemployment and labour...

Zb. rad. Ekon. fak. Rij. • $2017 \cdot$ vol. 35 • no. $1 \cdot 13-44$

Table 2: Occupational mismatch indexes in the EU countries 2007-2013

- in $\%$

\begin{tabular}{|c|c|c|c|c|c|c|c|c|c|}
\hline $\begin{array}{l}\text { Countries/ } \\
\text { time }\end{array}$ & 2007 & 2008 & 2009 & 2010 & 2011 & 2012 & 2013 & 2014 & 2015 \\
\hline Belgium & 61.19 & 60.08 & 56.22 & 52.27 & 66.85 & 65.36 & 60.64 & 57.48 & 59.37 \\
\hline Bulgaria & 90.91 & 60.57 & 80.09 & 83.37 & 80.00 & 83.64 & 82.22 & 96.13 & 77.51 \\
\hline $\begin{array}{l}\text { Czech } \\
\text { Republic }\end{array}$ & 77.42 & 75.01 & 74.33 & 75.64 & 71.83 & 70.98 & 70.49 & 72.83 & 64.31 \\
\hline Denmark & 72.97 & 70.39 & 60.71 & 64.75 & 69.75 & 74.51 & 72.85 & 76.61 & 82.46 \\
\hline Germany & 65.19 & 65.00 & 63.68 & 61.58 & 67.66 & 68.61 & 67.01 & 65.45 & 64.95 \\
\hline Estonia & 55.50 & 68.91 & 89.30 & 74.31 & 67.55 & 77.06 & 66.42 & 59.75 & 62.28 \\
\hline Ireland & 68.51 & 79.75 & 83.11 & 79.69 & 76.64 & 76.99 & 70.32 & 68.22 & 68.86 \\
\hline Greece & 74.49 & 74.16 & 71.93 & 71.84 & 80.61 & 80.43 & 77.80 & 80.11 & 80.80 \\
\hline Spain & 93.97 & 93.59 & 91.07 & 90.07 & 93.12 & 91.36 & 93.21 & 99.71 & 106.35 \\
\hline France & 59.29 & 59.29 & 59.29 & 59.29 & 59.29 & 62.10 & 58.77 & 58.95 & 60.34 \\
\hline Croatia & 82.89 & 88.08 & 78.53 & 74.05 & 76.15 & 75.85 & 78.23 & 87.88 & 88.22 \\
\hline Italy & 73.00 & 73.62 & 73.17 & 73.77 & 80.72 & 81.66 & 84.35 & 84.97 & 84.96 \\
\hline Cyprus & 78.10 & 80.27 & 74.43 & 75.88 & 79.14 & 69.60 & 72.05 & 69.51 & 70.02 \\
\hline Latvia & 71.68 & 75.21 & 77.37 & 70.27 & 77.00 & 85.29 & 89.45 & 87.28 & 83.81 \\
\hline Lithuania & 54.48 & 59.25 & 99.02 & 90.95 & 88.35 & 93.28 & 93.85 & 98.57 & 91.20 \\
\hline Luxembourg & 59.36 & 68.30 & 52.00 & 44.27 & 46.86 & 53.59 & 61.78 & 52.37 & 54.18 \\
\hline Hungary & 80.06 & 84.50 & 80.29 & 76.40 & 83.75 & 85.69 & 87.91 & 88.80 & 95.25 \\
\hline Malta & 67.39 & 70.42 & 73.12 & 76.11 & 67.11 & 68.21 & 70.64 & 71.52 & 73.15 \\
\hline Netherlands & 55.09 & 80.12 & 46.71 & 51.59 & 58.58 & 61.90 & 58.29 & 57.48 & 68.47 \\
\hline Austria & 71.06 & 74.41 & 69.14 & 72.64 & 73.72 & 70.41 & 71.17 & 67.77 & 70.19 \\
\hline Poland & 80.83 & 77.07 & 78.72 & 77.16 & 79.85 & 77.88 & 78.05 & 78.00 & 75.95 \\
\hline Portugal & 71.82 & 73.60 & 81.32 & 82.47 & 71.93 & 68.93 & 65.37 & 63.21 & 60.46 \\
\hline Romania & 99.89 & 95.34 & 88.42 & 90.60 & 91.08 & 87.94 & 90.73 & 84.88 & 87.07 \\
\hline Slovenia & 60.36 & 58.23 & 67.02 & 57.48 & 84.29 & 82.49 & 85.80 & 64.84 & 58.19 \\
\hline Slovakia & 82.81 & 77.43 & 84.23 & 80.67 & 78.87 & 80.32 & 79.50 & 77.27 & 74.21 \\
\hline Finland & 69.40 & 61.45 & 60.94 & 60.35 & 62.99 & 64.33 & 62.12 & 64.04 & 61.44 \\
\hline Sweden & 70.39 & 71.27 & 69.23 & 71.40 & 82.97 & 79.74 & 82.84 & 78.43 & 82.24 \\
\hline $\begin{array}{l}\text { United } \\
\text { Kingdom }\end{array}$ & 68.17 & 62.36 & 53.06 & 59.22 & 65.62 & 62.53 & 65.03 & 69.22 & 71.02 \\
\hline
\end{tabular}

Source: EUROSTAT, 2011; Authors' calculation

At the same time, particularly the countries with developed and stable economies have experienced in the recent years the smallest mismatch between jobs requirements and skills of the workforce, having the lowest occupational mismatch indices (Netherlands, Luxemburg, France, among others) unlike Baltic and the Mediterranean ones (Table 2). 


\subsection{Econometric analysis}

A) The first research objective of this paper was to measure the impact of real GDP growth on unemployment focusing on computing the coefficients that measure the rate of growth (gdp_r*) consistent with a stable unemployment rate and the long run impact of the growth rate on the change in unemployment $(\theta)$.

The following econometric approach has been applied:

a) Integration Analysis.

b) Co-Integration Analysis.

c) Parameters estimation.

d) Testing the most important hypotheses and the parameters.

a) The first stage of econometric approach consisted in panel integration analysis. Regarding the unemployment rates among different categories of unemployed, the tests applied in order to verify the null hypothesis of the existence of a unit root (in level) have had moreover mixed results. If we follow the results of the Im, Pesaran and Shin W-stat test, appreciated to be stronger than the other, we can consider these series integrated I $(0)$ at $p<0.01$ or $p<0.05$ (Table A2). As for the real GDP growth rate, all the test have rejected the null hypothesis of a unit root, this series being $\mathrm{I}(0)$ at $\mathrm{p}<0.01$.

b) Co-Integration analysis has tested the null hypothesis of no co-integration for the variables that we intend to include in 4 regression equations: unemployment rate (total), unemployment rate (old), unemployment rate (young), unemployment rate (low), as dependent variables and GDP growth rate as explanatory variable.The results of the tests have been rather divergent: Pedroni (Engle-Granger based) test suggests accepting the null hypothesis of no co-integration, while Kao (Engle-Granger based) and Fisher (combined Johansen) to reject the null hypothesis. If we use the results of the Kao test in order to take the final decision, being more powerful than other when the time span is not too large we can accept the existence of a long-term relationship between variables, except for the case of old unemployment rate (Table 3).

Table 3: Cointegration test

\begin{tabular}{|l|c|c|}
\hline \multicolumn{1}{|c|}{ Kao (Engle-Granger based) Test } & t-Statistic & Prob. \\
\hline Unemployment rate (total), GDP growth rate & -3.485 & 0.000 \\
\hline Unemployment rate (young), GDP growth rate & -3.355 & 0.000 \\
\hline Unemployment rate (old), GDP growth rate & -0.448 & 0.327 \\
\hline Unemployment rate (low), GDP growth rate & -3.524 & 0.000 \\
\hline
\end{tabular}

Note: $\mathrm{H}_{0}$ : No co-integration. P-values are reported in parenthesis. The optimal lag length was chosen by Schwarz Information Criterion (SIC).

Source: Authors' calculation 
c) Parameters estimation. In that all the series have proved to be $\mathrm{I}(0)$ integrated and the co-integration analysis demonstrated the long-term relation between dependent and explanatory variable, except for the case of older person unemployment, the next step in the empirical analysis has been parameter estimation. However, selecting the methods to be employed for parameter estimation took into consideration the fact that the results of integration and co-integration analysis have been not so clear cut. Thus, in a first step TSLS method has been applied to estimate the equation (5) and then ARDL model has been used to check the consistency of the previous results, the latter having the advantage to be suitable for stationary or non-stationary series.

Thus, using Okun's Law and estimating equation (5) by means of instruments (Panel Two-Stage EGLS), the first model (M1) examines the extent to which GDP growth explains changes in unemployment in the 28 European Union countries, during 1997-2015.

Regression coefficients are significant and the whole model is valid. The model explains $60 \%$ of the dependent variable variation (Adjusted R-squared $=0.597$ ). The growth rate that would ensure a stable unemployment rate is gdp_r ${ }^{*}=2.25 \%$ and the long-term effect is $\theta=-0.704$ (see equations 2 and 4 for their calculation formula). The short run effect of economic growth is -0.339 , while the lagged dependent variable that measures the process of adjusting is 0.518 (Table 4).

In terms of vulnerable groups, regression results show that the rate of growth which can maintain the change in unemployment rate constant should be $2.42 \%$ for young unemployed (M2), $1.05 \%$ for the older (M3) and 2.26\% for the low educated (M4). Moreover, the long run effect of the growth $(\theta)$ is higher for young $(-1.158)$ and those with a low level of education (-1.125).

In the older unemployed case, economic growth has a lower short run effect compared to the other two categories (i.e. the lowest coefficient of the variable the annual growth rate was of -0.223). The unemployment rate in their case has undergone a process of adjusting faster than the other two categories (the coefficient of lagged dependent variable is 0.750 compared to 0.396 for young and 0.555 for those low educated). 
Table 4: Panel country analysis: Panel Two-Stage EGLS (Cross-section weights)

\begin{tabular}{|c|c|c|c|c|}
\hline $\begin{array}{l}\text { Dependent variable: } \\
\qquad \Delta \mathrm{u}_{\mathrm{it}}\end{array}$ & $\begin{array}{l}\mathrm{M}^{5} \\
\text { (total) }\end{array}$ & $\begin{array}{c}\mathrm{M} 2^{6} \\
\text { (young people) }\end{array}$ & $\begin{array}{c}\mathrm{M}^{7} \\
\text { (older people) }\end{array}$ & $\begin{array}{c}\mathrm{M}^{8} \\
\text { (low educated } \\
\text { people) }\end{array}$ \\
\hline Constant & $\begin{array}{c}0.763^{* * *} \\
(0.167)\end{array}$ & $\begin{array}{c}1.688^{* * *} \\
(0.272)\end{array}$ & $\begin{array}{c}0.235^{* * *} \\
(0.051)\end{array}$ & $\begin{array}{l}1.128^{* *} \\
(0.229)\end{array}$ \\
\hline The annual growth rate & $\begin{array}{r}-0.339^{* * *} \\
(0.022)\end{array}$ & $\begin{array}{l}-0.698^{* * *} \\
(0.052)\end{array}$ & $\begin{array}{r}-0.223^{* * *} \\
(0.022)\end{array}$ & $\begin{array}{r}-0.500^{* * * *} \\
(0.044)\end{array}$ \\
\hline $\begin{array}{l}\text { Lagged dependent } \\
\text { variable }\end{array}$ & $\begin{array}{c}0.518^{* * *} \\
(0.073)\end{array}$ & $\begin{array}{c}0.396^{* * *} \\
(0.084)\end{array}$ & $\begin{array}{c}0.750^{* * *} \\
(0.120)\end{array}$ & $\begin{array}{r}0.555^{* * *} \\
(0.101)\end{array}$ \\
\hline Observations & 308 & 308 & 252 & 308 \\
\hline Adjusted R-squared & 0.597 & 0.496 & 0.303 & 0.402 \\
\hline F-statistic & 73.571 & 51.252 & 44.678 & 43.530 \\
\hline Growth $\left(\mathrm{g}^{*}\right)$ & $\begin{array}{c}2.248^{* * *} \\
(0.408)\end{array}$ & $\begin{array}{c}2.416^{* * *} \\
(0.299)\end{array}$ & $\begin{array}{c}1.052^{* * *} \\
(0.236)\end{array}$ & $\begin{array}{l}2.256^{* * *} \\
(0.356)\end{array}$ \\
\hline Theta $(\theta)$ & $\begin{array}{r}-0.704^{* * *} \\
(0.134)\end{array}$ & $\begin{array}{r}-1.158^{* * *} \\
(0.204)\end{array}$ & $\begin{array}{r}-0.891^{* * *} \\
(0.480)\end{array}$ & $\begin{array}{r}-1.125^{* * *} \\
(0.316)\end{array}$ \\
\hline Prob (J-statistic) & 0.321 & 0.180 & 0.136 & 0.280 \\
\hline Prob (Pesaran CD test) & 0.461 & 0.100 & 0.145 & 0.920 \\
\hline Prob (Jarque-Bera test) & 0.890 & 0.498 & 0.658 & 0.943 \\
\hline
\end{tabular}

Note: Significance: ${ }^{* * *} \mathrm{p}<0.01,{ }^{* *} \mathrm{p}<0.05,{ }^{*} \mathrm{p}<0.1$ (standard errors are in brackets). The instruments have been: time period dummies, differenced dependent variable with different lags and differenced independent variable with lags. H0: over identifying restrictions are valid Sargan test (J-statistic). H0: no cross-section dependence (correlation) in weighted residuals - Pesaran CD test. H0: normally distributed errors - Jarque-Bera test. A dummy variable has been used as control variable for the period of the economic crisis and after.

Source: Authors' calculation

B) The second objective of this paper was to test the influence of mismatches related to skills on unemployment dynamics. Educational and occupational mismatch indexes have been used as explanatory variables in the model that describes the inverse relationship between unemployment and GDP.

5 Instrument specification: c d(uit(-7)) d(gdpit) d(gdpit(-1)) Dummy(2007) Dummy(2008) Dummy(2009) Dummy(2010)

${ }^{6}$ Instrument specification: c d(uit_young(-7)) d(gdpit) d(gdpit(-1)) Dummy(2005) Dummy(2006) Dummy(2007) Dummy(2008)

7 Instrument specification: c d(uit_old(-9)) d(gdpit) d(gdpit(-1)) Dummy(2005) Dummy(2006) Dummy(2007) Dummy(2008)

8 Instrument specification: c d(uit_low(-7)) d(gdpit) d(gdpit(-1)) Dummy(2006) Dummy(2007) Dummy(2008) Dummy(2009) 
In this case, Autoregressive Distributed Lag (ARDL) model has been preferred as it has as one of the main advantages the possibility to be applied to stationary or non-stationary series. In addition, it allows catching both long and short run relationships between variables and can be used to reinforce the previous findings. Mismatch indexes (occupational and educational) have been included in the equation (9), but only occupational mismatches have been retained into analysis due to the fact that they have proved a significant impact on unemployment rates of all the four categories analysed: adult, young, old and low educated, better explaining the influence of skill mismatch on unemployment dynamics.

Table 5: Panel country analysis: Autoregressive Distributed Lag (ARDL) Model

\begin{tabular}{|c|c|c|c|c|c|c|c|c|}
\hline \multirow{2}{*}{$\begin{array}{l}\text { Dependent } \\
\text { variable: } \\
\mathrm{D}\left(\log \left(\mathrm{ur}_{\mathrm{it}}\right)\right)\end{array}$} & \multicolumn{2}{|c|}{ Total } & \multicolumn{2}{|c|}{ Young people } & \multicolumn{2}{|c|}{ Older people } & \multicolumn{2}{|c|}{$\begin{array}{l}\text { Low educated } \\
\text { people }\end{array}$} \\
\hline & M5 & M5' & M6 & M6' & M7 & M7' & M8 & M8' \\
\hline $\begin{array}{l}\text { Long run } \\
\text { coefficient } \\
\left(\theta_{i}\right)\end{array}$ & $\begin{array}{r}-0.875^{* * *} \\
(0.181)\end{array}$ & $\begin{array}{r}-0.985^{* *} \\
(0.163)\end{array}$ & $\begin{array}{r}-1.652^{* * *} \\
(0.187)\end{array}$ & $\begin{array}{r}-1.291^{* * *} \\
(0.188)\end{array}$ & $\begin{array}{r}-1.545^{* * *} \\
(0.211)\end{array}$ & $\begin{array}{r}-1.190^{* * *} \\
(0.210)\end{array}$ & $\begin{array}{r}-1.195^{* * *} \\
(0.218)\end{array}$ & $\begin{array}{r}-0.704^{* * *} \\
(0.193)\end{array}$ \\
\hline Log(omi) & & $\begin{array}{r}1.122^{* * *} \\
(0.205)\end{array}$ & & $\begin{array}{r}1.124^{* * *} \\
(0.219)\end{array}$ & & $\begin{array}{r}0.586^{* * *} \\
(0.247)\end{array}$ & & $\begin{array}{r}1.741^{* * *} \\
(0.188)\end{array}$ \\
\hline $\begin{array}{l}\text { Error } \\
\text { correction } \\
\text { coefficient } \\
\left(\phi_{i}\right)\end{array}$ & $\begin{array}{r}-0.268^{* * *} \\
(0.039)\end{array}$ & $\begin{array}{r}-0.257^{* * *} \\
(0.043)\end{array}$ & $\begin{array}{r}-0.253^{* * *} \\
(0.044)\end{array}$ & $\begin{array}{r}-0.226^{* * *} \\
(0.049)\end{array}$ & $\begin{array}{r}-0.364^{* * *} \\
(0.039)\end{array}$ & $\begin{array}{r}-0.349^{* * *} \\
(0.042)\end{array}$ & $\begin{array}{r}-0.203^{* * *} \\
(0.027)\end{array}$ & $\begin{array}{r}-0.196^{* * *} \\
(0.048)\end{array}$ \\
\hline $\mathrm{D}\left(\log \left(\mathrm{ur}_{\mathrm{it}-1}\right)\right)$ & $\begin{array}{r}0.279^{* * *} \\
(0.058)\end{array}$ & $\begin{array}{r}0.285^{* * *} \\
(0.057)\end{array}$ & & & & & & \\
\hline $\mathrm{D}(\log (\mathrm{gdp}))$ & $\begin{array}{r}-3.049^{* * *} \\
(0.417) \\
\end{array}$ & $\begin{array}{r}-2.940^{* * *} \\
(0.438) \\
\end{array}$ & $\begin{array}{r}-2.816^{* * *} \\
(0.432)\end{array}$ & $\begin{array}{r}-2.995^{* * *} \\
(0.481)\end{array}$ & $\begin{array}{r}-0.888^{* * *} \\
(0.537)\end{array}$ & $\begin{array}{l}-1.096^{*} \\
(0.646)\end{array}$ & $\begin{array}{r}-2.462^{* * *} \\
(0.455)\end{array}$ & $\begin{array}{c}-2.717^{* * *} \\
(0.602)\end{array}$ \\
\hline $\mathrm{D}(\log ($ omi $))$ & & $\begin{array}{l}-0.108 \\
(0.088)\end{array}$ & & $\begin{array}{l}-0.032 \\
(0.085)\end{array}$ & & $\begin{array}{l}-0.311^{*} \\
(0.172)\end{array}$ & & $\begin{array}{l}-0.148 \\
(0.096)\end{array}$ \\
\hline $\mathrm{c}$ & $\begin{array}{r}3.295^{* * *} \\
(0.422)\end{array}$ & $\begin{array}{r}2.193^{* * *} \\
(0.318)\end{array}$ & $\begin{array}{r}5.379^{* * *} \\
(0.818)\end{array}$ & $\begin{array}{r}2.735^{* * *} \\
(0.536)\end{array}$ & $\begin{array}{l}7.016^{* * * *} \\
(0.721)\end{array}$ & $\begin{array}{r}4.403^{* * *} \\
(0.487)\end{array}$ & $\begin{array}{r}3.288^{* * *} \\
(0.419)\end{array}$ & $\begin{array}{r}0.593^{* * *} \\
(0.136)\end{array}$ \\
\hline $\begin{array}{l}\text { Selected } \\
\text { Model }\end{array}$ & $\begin{array}{c}\text { ARDL } \\
(2,1,1) \\
\end{array}$ & $\begin{array}{c}\text { ARDL } \\
(2,1,1)\end{array}$ & $\begin{array}{c}\text { ARDL } \\
(1,1,1) \\
\end{array}$ & $\begin{array}{c}\text { ARDL } \\
(1,1,1)\end{array}$ & $\begin{array}{l}\text { ARDL } \\
(1,1,1)\end{array}$ & $\begin{array}{c}\text { ARDL } \\
(1,1,1) \\
\end{array}$ & $\begin{array}{c}\text { ARDL } \\
(1,1,1)\end{array}$ & $\begin{array}{c}\text { ARDL } \\
(1,1,1)\end{array}$ \\
\hline
\end{tabular}

Note: Significance: ${ }^{* * *} \mathrm{p}<0.01,{ }^{* *} \mathrm{p}<0.05,{ }^{*} \mathrm{p}<0.1$ (standard errors are in brackets). Model selection method: Schwarz criterion (SIC). A dummy variable has been used as control variable for the period of the economic crisis and after.

Source: Authors' calculation

Table 5 contains the results for total unemployment rate, in the column total, and for young, older and low educated people, in the next columns. Each of the top columns was divided into two models, the second including occupational mismatches. What is noteworthy about these results is that the insertion of occupational mismatches into the models has led to a decrease in the sensitivity of unemployment to output fluctuations for all three categories of vulnerable workers in long run. 
Thus, error correction coefficient is negative and statistically significant for total unemployment (-0.257 for M5') and for vulnerable groups (-0.226 for M6', -0.349 for M7' and - 0.196 for M8') which can be interpreted as evidence of long run cointegration relationship between unemployment and GDP.

The long run coefficient that measures the same relationship is significant and negative for all categories, indicating an inverse relationship between unemployment and GDP in the long-term. More precisely, when the economic growth increases $1 \%$, growth in the unemployment rate decreases $0.99 \%$ for total unemployment, $1.29 \%$ for young unemployed, $1.19 \%$ for older people unemployment and $0.70 \%$ for low educated people unemployment. The same negative relationship is valid on short time and even in this case the largest elasticity can be observed for young people unemployment rate (short run coefficient is -2.995 , compared to -1.096 for older and -2.717 for low educated unemployed).

In terms of mismatches, occupational ones seem to have moreover a long-term influence on unemployment rate of different groups of labour market participants than a short run impact: the long run coefficients are significant and positive, ranging from 1.124 for youth unemployment to 0.586 for older people. The short run coefficients are significant only for older people, but the relationship appear to be negative (short run coefficient is -0.311).

\section{Results and discussion}

The main aim of this paper was to study why, even nowadays, unemployment rate in the European Union countries has remained very high, almost double compared to general rate for some vulnerable groups such as young or low educated people. Recent economic literature has highlighted two major reasons: poor structure of many European economies, unable to provide a number of jobs comparable to the number of those seeking to be employed and increasing imbalances between labour market requirements and labour force qualifications (in many countries coexisting vacancies and high unemployment).

Analysing the period 1997-2015 by means of Box Plots and Kernel Density graphs we showed that recently, economic growth rate has returned to an upward trend in most of the European Union countries and differences between them are in decline. As regards unemployment rates of certain categories of participants in the labour market, even the minimum levels of these indicators are on the rise and so are the differences between countries. Moreover, Kernel Density graphs point to the clear delimitation of at least two groups of countries in terms of the level reached by unemployment rates. Mediterranean countries record the highest levels of these indicators among young people or even older ones and countries such as Slovakia, Lithuania and Latvia have problems in terms of unemployment among people with a low level of education. 
An explanation of these imbalances could be the presence of mismatches. In this paper we have addressed the problem of educational and occupational mismatches. By using Educational Mismatch Index and Occupational Mismatch Index we showed that there are countries where these mismatches are large or very large, mainly because of the problems that people with low a low level of education and those with elementary occupations have in finding a job.

Using a panel data set for the $28 \mathrm{EU}$ countries (until 2015) and a period of 19 years (1997-2013), 12 regression models have been estimated based on Okun's Law, dynamic version: the first four by means of Two Stage Least Square (TSLS) method and the remaining ones by applying Autoregressive Distributed Lag (ARDL) method.

TSLS method, applied in order to estimate equation (5), has led to the following result: changes in young and low educated people unemployment rates are conditioned to a greater extent by the dynamics of the economic growth. Instead, the unemployment rate among older people showed a greater capacity of adjustment.

In addition, including educational and occupational indexes as explanatory variables in an ARDL model, that captures the relationship between unemployment rate and GDP, reinforced the previous results and showed further that occupational mismatches have a significant long-term impact on all the categories of unemployed analysed, most affected being the young and those low educated. The short run effect is rather mixed, varying across different countries.

Our paper' results are in line with the latest research findings in the field, but bring also a novelty element by addressing the impact on unemployment rate of some cyclical and structural factors both on short and long-term. Thus, in addition to the fact shown also in other studies, that GDP growth rate influences to a greater extent unemployment among young people, our results draw attention that the long run consequences of this impact are at least two: the major risk that these young people become mismatched and long-term unemployed, or to form a mass of working poor employed.

Regarding the category of people with a low level of education, the main risk that we have anticipated is that, in the long-term, they could be threatened by unemployment spells, although nowadays in many countries they are still a desired work force, being cheap. Instead, a group that cannot be considered very vulnerable is the elderly, for at least two reasons: demographic developments will lead to narrowing labour resources and young people which should provide the replacement workforce may not possess the necessary qualifications and experience.

In terms of skills mismatch, our analysis led us to conclude that they should not be treated as having insignificant impact on future labour market equilibrium since, in 
the long-term, they will influence the unemployment rate, as well as the quality of employment and life of the vulnerable groups. Therefore, tackling unemployment problem among vulnerable groups through public policies should, in our view, be made on medium and long-term and have, as far as possible, a unitary approach at the EU level, particularly as nowadays transnational labour movement cannot be neglected.

In the future, besides economic recovery, active policies, mainly those 'that support long-term unemployed and vulnerable workers to avoid a rise in the structural unemployment' (Furceri and Mourougane, 2012, pp. 401) will play an essential role in stimulating the functioning of the labour market. At the same time, labour market institutions need to become themselves more adaptable, as they can be a source of labour market rigidities (Şerban et al., 2013).

\section{Conclusions}

If the financial crisis has been overcome, even nowadays we can talk of a labour market crisis that requires long-term solutions for diminishing the problem of unemployment, the consequences of mismatches and the direct effects that they have on both workers' quality of life and the prospects for a sustainable economic growth (Dimian et al., 2013).

Having set the main objective to investigate some of the most significant drivers of high unemployment rates in the European Union countries during recent period, we have concentrated our study on testing:

1. Whether changes in GDP growth rate have to a greater extent influenced certain categories of unemployed considered vulnerable under crisis conditions. We have demonstrated that, together with low educated workers, mainly young people are the most affected group, both in short and long run, keeping in mind that in turbulent economic times companies are less willing to invest resources in their training and look for more experienced workers. Moreover, in countries where collaboration between companies and the education system is deficient, mismatches deepen between jobs requirements of workers' qualifications and might lead to an increase in unemployment among young people.

2. If educational and occupational mismatches have had a significant impact on unemployment rate in short and long-term. We have proved that occupational mismatches have a greater impact on young and low educated people, particularly in the long run. In the short-term, policies promoted in most countries, aiming at increasing employment through fixed-term or part time contracts, successfully contribute to reducing unemployment, but in the long run, in the absence of effective policies of training and retraining, lifelong learning, mismatches will lead 
to a mass of workers threatened by long-term unemployment or poor working and low standards of living.

Besides its main aim, to analyse both cyclical and structural causes of unemployment, this article proposes the use of some modern econometric methods such as Autoregressive Distributed Lag (ARDL), which allows capturing both short and longterm relationships, considering that the results of the studies carried out so far in the European Union countries have been rather ambiguous. The article also concentrates on vulnerable groups in the labour market (young, older and low educated people), given that public policies seeking to reduce unemployment should be targeted towards these categories.

Our results limitations are mainly related to the problem that also other authors have highlighted, namely of how mismatches can be measured. In this regard, we intend to extend the research carried out so far in several directions. One of them is approaching additional methods for measuring mismatches and testing their impact. Furthermore, interest for political decisions can be a deeper analysis of the differences across countries and, in this respect, ARDL method allows obtaining the results in the short-term at country level. Last but not least, another course of action could be the implementation of the model across economic sectors in order to highlight the opportunities that they can provide for creating jobs.

Certainly, generally applicable solutions cannot be found to solve the problem of unemployment in all European Union countries, but some directions of action can be highlighted. In developed countries, an important issue remains the mismatch between job requirements and characteristics of those who are looking for a job, while in the emerging ones, the challenge is represented by increasing the quality of jobs. Moreover, all countries could focus on investing in creating green jobs that have a dual role, the unemployed absorption and sustainable economic growth. In this regard, both young and people with lower education levels should be educated/oriented towards the sectors of activity that can contribute to green growth. Those countries with educational systems not well connected to labour market requirements might consider creating visionary policies in order to anticipate future skills needs. In this regard, not only a very good planning of future labour markets is a must, but also a reform of public institutions that should implement these plans.

\section{References}

Apergis, N., Rezitis, A. (2003) "An examination of Okun's law: evidence from regional areas in Greece", Applied Economics, Vol. 35, No. 10, pp. 1147-1151, doi: $10.1080 / 0003684032000066787$. 
Ball, L. et al. (2015) "Does One Law Fit All? Cross-Country Evidence on Okun's Law", IMF Working Paper.

Barlevy, G. (2011) "Evaluating the Role of Labor Market Mismatch in Rising Unemployment", Economic Perspectives, Vol. 35, No. 3, pp. 82-96.

Bauer, A. (2013) "Mismatch unemployment. Evidence from Germany, 2000-2010", IAB-Discussion Paper, No. 10.

Bell, D.N.F, Blanchflower, D. G. (2011) "Young people and the Great Recession", Oxford Review of Economic Policy, Vol. 27, No. 2, pp. 241-267, doi: 10.1093/ oxrep/grr011.

Binet, M., Facchini, F. (2013) "Okun's law in the French regions: a cross-regional comparison", Economics Bulletin, Vol. 33, No. 1, pp. 420-433. Available at: $<$ http://www.accessecon.com/Pubs/EB/2013/Volume33/EB-13-V33-I1-P41. pdf $>$ [Accessed: March 7, 2016].

Canon, M. E., Chen, M., Marifian, E.A. (2013) "Labor Mismatch in the Great Recession: A Review of Indexes Using Recent U.S. Data", Federal Reserve Bank of St. Louis Review, May/June 2013, Vol. 95, No. 3, pp. 237-271.

Dixon, R. Lim, G.C., van Ours, J.C. (2017) "Revisiting the Okun relationship", Applied Economics, Vol. 49, No. 28, pp. 2749-2765, doi: 10.1080/00036846. 2016.1245846.

Cazes, S., Verick, S., Al Hussami, F. (2013) "Why did unemployment respond so differently to the global financial crisis across countries? Insights from Okun's Law", IZA Journal of Labor Policy, Vol. 2, No.10, pp. 1-18, doi: 10.1186/21939004-2-10.

European Centre for the Development of Vocational Training - CEDEFOP (2016) Skills development and matching in the EU, Greece: Employment and social developments in Europe 2015.

Christopoulos, D. (2004) "The relationship between output and unemployment: Evidence from Greek Regions", Papers in Regional Sciences, Vol. 83, No. 3, pp. 611-620, doi: 10.1111/j.1435-5597.2004.tb01928.x.

Dritsaki, C., Dritsakis, N. (2009) "Okun's Coefficient for Four Mediterranean Member Countries of EU: An Empirical Study", International Journal of. Business and Management, Vol. 4, No. 5, pp. 18-26, doi: 10.5539/ijbm.v4n5p18.

Dimian, G.C. et al. (2013) "Analysis of European Labour Market in the Crisis Context", Prague Economic Papers, Vol. 22, No. 1, pp. 50-71, doi: 10.18267/j. pep. 440 .

Durech, R. et al. (2014) "Regional evidence on Okun's law in Czech Republic and Slovakia”, Economic Modelling, Vol. 42, pp. 57-65, doi: 10.1016/j.econmod. 2014.05.039.

Elsby, M.W.L. et al. (2011) "The Labor Market in the Great Recession - An Update to September 2011", Brookings Papers on Economic Activity, pp. 353-384, doi: 10.1353/eca.2011.0013. 
European Commission (EC), Directorate-General for Economic and Financial Affairs (2013) Labour Market Developments in Europe, 2013. Brussels: European Economy No. 6.

Eurostat - Statistics Explained - Europa.eu (2016) Unemployment statistics, Job Vacancy Statistics and National accounts.

Freeman, D. G. (2000) "Regional tests of Okun's law", International Advances in Economic Research, Vol. 6, No. 3, pp. 557-570, doi: 10.1007/bf02294972.

Furceri, D., Mourougane, A. (2012) "How Do Institutions Affect Structural Unemployment in Times Of Crisis?", Panoeconomicus, Vol. 4, pp. 393-419, doi: 10.2298/pan1204393f.

Hornstein, A. (2012) "Accounting for Unemployment: The Long and Short of It", FRB Richmond Working Paper No. 12-07. (November 5). Available at: $<\mathrm{https}$ :// ssrn.com/abstract=2191168> [Accessed: March 16, 2015]

Huang (River), H.C., Yeh, C.C. (2013) "Okun's law in panels of countries and states", Applied Economics, Vol. 45, No. 2, pp. 191-199, doi: 10.1080/00036846.2011. 597725.

Hutengs, O., Stadtmann, G. (2014) "Age- and gender-specific unemployment in Scandinavian countries: An analysis based on Okun's law", Comparative Economic Studies, Vol. 56, No. 4, pp. 567-580, doi: 10.1057/ces.2014.22.

Hurlin, C. (2010) "Dynamic Panel Data Models", University of Orleans's, 2010, [Internet]. Available at: <http://www.univ-orleans.fr/deg/masters/ESA/CH/ Geneve_Chapitre2.pdf> [Accessed: 26.01.2017].

International Monetary Fund - IMF (2010) World economic outlook. Rebalancing growth. Washington, DC: World economic and financial surveys, April 2010, doi: 10.5089/9781589069572.081.

International Monetary Fund - IMF (2015) Youth Unemployment in Advanced Europe: Okun's Law and Beyond. Washington, DC: IMF Working Paper, WP/15/5, January, doi: 10.5089/9781498382519.001.

Kangasharju, A., Tavera, C., Nijkamp, P. (2012) "Regional growth and unemployment: the validity of Okun's law for the Finnish regions", Spatial Economic Analysis, Vol. 7, No. 3, pp. 381-395, doi: 10.1080/17421772.2012.694141.

Kargi, B. (2013) "Okun's Law and Long Term Co-Integration Analysis for OECD Countries (1987-2012)", International Research Journal of Finance and Economics, Vol. 119, No. 55700, pp. 77-85, doi: 10.2139/ssrn.2439235.

Knotek, E.S. (2007) "How Useful is Okun's Law?. Economic review, fourth quarter 2007”, Federal Reserve Bank of Kansas City, pp. 73-103.

Lee, J. (2000) "The robustness of Okun's Law -Evidence from OECD countries", Journal of Macroeconomics, Vol. 22, No. 2, pp. 331-356, doi: 10.1016/S01640704(00)00135-X.

Obadić, A. (2006) "Theoretical and Empirical Framework of Measuring Mismatch on a Labour Market", Zbornik radova Ekonomskog fakulteta u Rijeci: časopis 
za ekonomsku teoriju i praksu/Proceedings of Rijeka Faculty of Economics: Journal of Economics and Business, Vol. 24, No. 1, pp. 55-80.

Okun, A. M. (1962) "Potential GNP: Its Measurement and Significance", American Statistical Association, Proceedings of the Business and Economics Statistics Section, pp. 98-104.

Rothstein, J. (2012) "The Labor Market Four Years into the Crisis: Assessing Structural Explanations", NBER Working Paper No. 17966, doi: 10.3386/w17966.

Sahin, A. et al. (2012) "Mismatch unemployment", NBER Working Paper No. 18265, doi: $10.3386 / \mathrm{w} 18265$.

Smith, J.C. (2012) "UK unemployment dynamics during the financial crisis. Unemployment and mismatch in the UK", Paper presented at: Chief Economists' Workshop: "Labour market dynamics during the financial crisis: puzzles for policymakers", Bank of England.

Smith, R. (2010) Okun's Law. Applied Statistics and Econometrics, Birkbeck.

Sögner, L., Stiassny, A. (2002) "An analysis on the structural stability of Okun's law: a cross-country study", Applied Economics, Vol. 34, No. 14, pp. 17751787, doi: 10.1080/00036840210124180.

Şerban, A. C., Aceleanu, M. I., Săseanu, A.S. (2013) “The role of labour market institutions in explaining labour market rigidities. The case of unemployment benefits", Actual Problems of Economics, Vol. 139, No. 1, pp. 545-552.

Tatoğlu, F. Y. (2011) "The long and short run effects between unemployment and economic growth in Europe", Dogus Universitesi Dergisi, Vol. 12, No. 1, pp. 99-113.

Tomić, I. (2016), What drives youth unemployment in Europe? EIZ-WP-1601, The Institute of Economics, Zagreb.

Valletta, R. (2013) “Long-term unemployment: what do we know?", FRBSF Economic Letter 3.

van Ours, J. C. (2015) “The Great Recession Was Not so Great”. Labour Economics, Vol. 34, pp. 1-12, doi: 10.1016/j.labeco.2015.02.001.

Villaverde, J., Maza, A. (2009) "The Robustness of Okun's Law in Spain, 19802004: Regional Evidence”, Journal of Policy Modelling, Vol. 31, No. 2, pp. 289-297, doi: 10.1016/j.jpolmod.2008.09.003.

Wooldridge, M. J. (2010) Introductory Econometrics: A modern Approach, 4 ed., Mason: South-Western Cengage Learning.

Zanin, L. (2014) "On Okun's law in OECD countries: an analysis by age cohorts", Economics Letters, Vol. 125, No. 2, pp. 243-248, doi: 10.1016/j.econlet.2014. 08.030 . 
Nezaposlenost i nepodudarnost tržišta rada u zemljama Europske Unije ${ }^{1}$

\author{
Gina Cristina Dimian ${ }^{2}$, Liviu Stelian Begu ${ }^{3}$, Josef Jablonsky ${ }^{4}$
}

\begin{abstract}
Sažetak
Svrha ovog rada je istražiti neke od glavnih uzroka visoke stope nezaposlenosti u zemljama Europske unije polazeći od dva ključna izvora u ekonomskoj literaturi: nedostatak ukupne potražnje i sve veće nepodudarnosti na tržištu rada. Analiza je provedena na temelju panel podataka i fokusira se na dva cilja: izmjeriti kratkoročni $i$ dugoročni utjecaj rasta BDP na nezaposlenost za razne kategorije sudionika na tržištu rada (mladi, stari $i$ radnici s nižom stručnom spremom) $i$ ocijeniti odnos nepodudarnosti između vještina (obrazovnih $i$ profesionalnih) $i$ nezaposlenosti. Jedan od glavnih zaključaka jest da su promjene u stopama nezaposlenosti mladih $i$ nisko obrazovanih osoba uvelike pod utjecajem dinamičnog ekonomskog rasta kako dugoročno, tako i kratkoročno, dok stope nezaposlenosti među starijima ukazuju na veću mogućnost prilagodbe. Nadalje, izgleda da profesionalna nepodudarnost ima značajan dugoročni utjecaj na promjenu u stopi nezaposlenosti svih kategorija nezaposlenih, dok je kratkoročni utjecaj mješovit i varira od zemlje do zemlje. Jedno objašnjenje je činjenica da se ekonomska struktura za vrijeme krize može mnogo brže mijenjati nego što se tržište rada i obrazovni sustav mogu prilagoditi.
\end{abstract}

Ključne riječi: nezaposlenost, ekonomski rast, nepodudarnost, panel podataka, dinamična ekonometrijska analiza

JEL klasifikacija: J62, J64, O4

1 Istraživanje podržava Češka znanstvena zaklada, projekt P402/12/G097 "DYME - Dynamic Models in Economics“/Dinamički modeli u ekonomiji.

2 Docentica, Faculty of Economic Cybernetics, Statistics and Informatics, Bucharest Academy of Economic Studies, Piata Romana Square 6, 1st district, Bukurešt, 010374 Rumunjska. Znanstveni interes: neravnoteža tržišta rada, međunarodne komparacije, regionalna konkurentnost, model panel podataka.Tel.: +40213191900.Fax: +402131918 99.E-mail: gina.dimian@csie.ase. ro (osoba za kontakt).

${ }^{3}$ Redoviti profesor, Faculty of Economic Cybernetics, Statistics and Informatics, Bucharest Academy of Economic Studies, Piata Romana Square 6, 1st district, Bukurešt, 010374 Rumunjska. Znanstveni interes: makroekonomija, ekonomska konvergencija, međunarodni odnosi, međunarodna statistika. Tel.: +40213191900.Fax: +40213191899.E-mail:liviu.begu@csie.ase.ro.

${ }^{4}$ Redoviti profesor, Faculty of Informatics and Statistics, University of Economics. W. Churchill Sq. 4, 13067 Prag 3, Republika Čěkka. Znanstveni interes: analiza učinkovitosti, analiza višestrukih kriterija, metode prikupljanja podataka. Tel.: +4202 2409 5403. Fax: +42022409 5423.E-mail: jablon@vse.cz.Osobnaweb stranica: http://webhosting.vse.cz/jablon. 

Gina Cristina Dimian, Liviu Stelian Begu, Josef Jablonsky • Unemployment and labour...

Zb. rad. Ekon. fak. Rij. • $2017 \cdot$ vol. 35 • no. $1 \cdot 13-44$

\section{Appendices}



Table A1: Variables description and data source

\begin{tabular}{|c|c|c|}
\hline Variable & Description & Data source \\
\hline Unemployment rate $(\%)$ & $\begin{array}{l}\text { An unemployed person is defined by Eurostat, } \\
\text { according to the guidelines of the International Labour } \\
\text { Organization, as someone aged } 15 \text { to } 74 \text { without work } \\
\text { during the reference week who is available to start } \\
\text { work within the next two weeks and who has actively } \\
\text { sought employment at some time during the last four } \\
\text { weeks. The unemployment rate is the number of } \\
\text { people unemployed as a percentage of the labour force. }\end{array}$ & Eurostat Database \\
\hline $\begin{array}{l}\text { Youth (young people) } \\
\text { unemployment rate }(\%)\end{array}$ & $\begin{array}{l}\text { It is the number of those unemployed divided by } \\
\text { the total number of people in the labour market } \\
\text { (employed plus unemployed) for the specific age } \\
\text { group, } 15-24 \text { years. }\end{array}$ & Eurostat Database \\
\hline $\begin{array}{l}\text { Older people } \\
\text { unemployment rate }(\%)\end{array}$ & $\begin{array}{l}\text { It is the number of those unemployed divided by } \\
\text { the total number of people in the labour market } \\
\text { (employed plus unemployed) for the specific age } \\
\text { group, 55-64 years. }\end{array}$ & Eurostat Database \\
\hline $\begin{array}{l}\text { Low educated people } \\
\text { unemployment rate }(\%)\end{array}$ & $\begin{array}{l}\text { It is the number of those unemployed divided by the } \\
\text { total number of people in the labour market (employed } \\
\text { plus unemployed) for a specific educational attainment } \\
\text { level, i.e. less than primary, primary and lower } \\
\text { secondary education (ISCED levels 0-2). }\end{array}$ & Eurostat Database \\
\hline $\begin{array}{l}\text { Real GDP growth } \\
\text { rate (a chain linked } \\
\text { volumes, percentage } \\
\text { change over previous } \\
\text { period) } \\
\end{array}$ & $\begin{array}{l}\text { It is measured as the GDP at current prices valued } \\
\text { in prices of the previous year and thus computed } \\
\text { volume changes are imposed on the level of a } \\
\text { reference year. Accordingly, price movements will } \\
\text { not inflate the growth rate. }\end{array}$ & Eurostat Database \\
\hline $\begin{array}{l}\text { Educational mismatch } \\
\text { indexes }(\%)\end{array}$ & $\begin{array}{l}\text { Has been computed as a measure of the gap between } \\
\text { the share of the educational group i in employment } \\
\left(n_{i}\right) \text { and the same share in total working age } \\
\text { population }\left(q_{i}\right) \text {, weighted with the category i share in } \\
\text { working age population }\left(q_{i}\right) \text { (European Commission, } \\
2013) . \\
E M I=\sum_{\mathrm{l}=1}^{n} q_{i} \cdot\left|q_{i}-n_{i}\right|,(i=\text { level of education: basic, } \\
\text { intermediate and advance). }\end{array}$ & $\begin{array}{l}\text { ILOSTAT } \\
\text { Database, own } \\
\text { calculations }\end{array}$ \\
\hline $\begin{array}{l}\text { Occupational mismatch } \\
\text { indexes }(\%)\end{array}$ & $\begin{array}{l}\text { Coefficients of variation of the ratio: number of } \\
\text { unemployed from a category of occupations (based } \\
\text { on previous occupations) and total number of } \\
\text { unemployed, for nine categories of occupations: } \\
\text { Managers, Professionals, Technicians and associate } \\
\text { professionals, Clerical support workers, Service } \\
\text { and sales workers, Skilled agricultural, forestry and } \\
\text { fishery workers, Craft and related trades workers, } \\
\text { Plant and machine operators, and assemblers and } \\
\text { Elementary occupations. }\end{array}$ & $\begin{array}{l}\text { Eurostat Database, } \\
\text { own calculations }\end{array}$ \\
\hline
\end{tabular}

Source: Eurostat Statistics Explained (2016): Unemployment statistics, Job Vacancy Statistics, National accounts and GDP 
Table A2: Panel Unit Root Tests

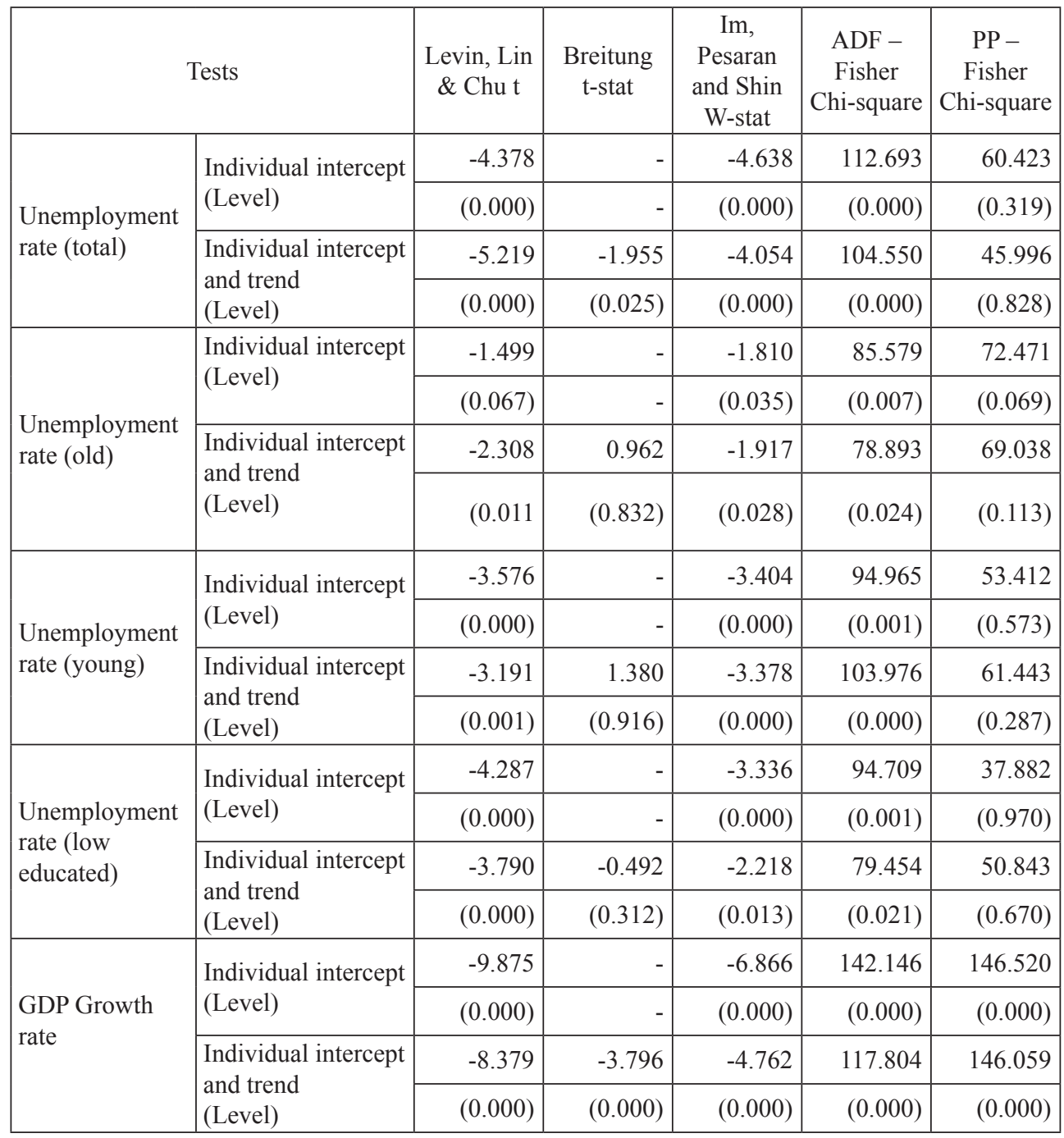

Note: $\mathrm{H}_{0}$ : Unit root. P-values are reported in parenthesis. The optimal lag length was chosen by Schwarz Information Criterion (SIC).

Source: Authors' calculation 
Gina Cristina Dimian, Liviu Stelian Begu, Josef Jablonsky • Unemployment and labour...

Figure A1: Box Plot and Kernel Density of GDP growth rate in the 28 EU countries, $1997-2015(\%)$
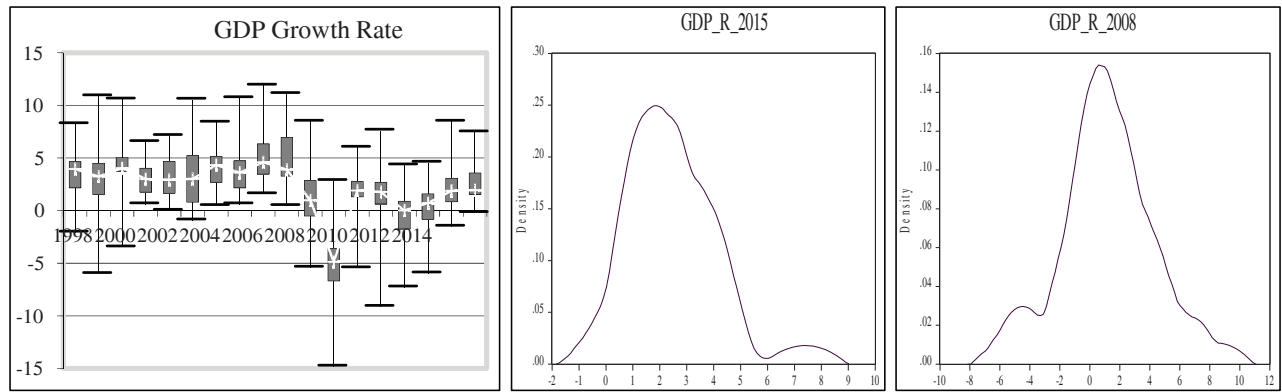

Source: EUROSTAT, 2016; Authors' calculation 
Gina Cristina Dimian, Liviu Stelian Begu, Josef Jablonsky • Unemployment and labour... Zb. rad. Ekon. fak. Rij. $\cdot 2017 \cdot$ vol. $35 \cdot$ no. $1 \cdot 13-44$

Figure A2: Box Plots and Kernel Density of unemployment rates in the $28 \mathrm{EU}$ countries, $1997-2015(\%)$
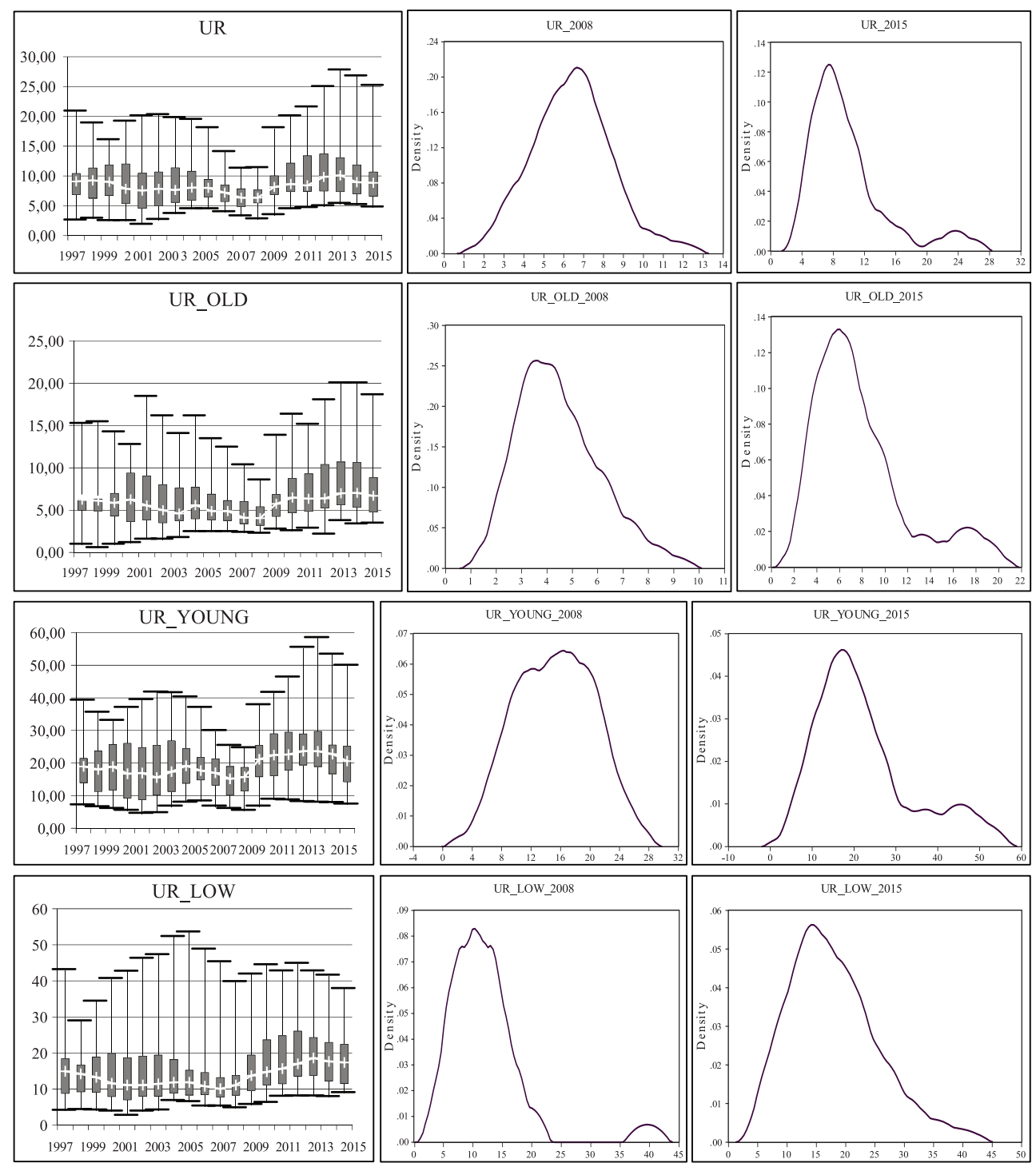

Source: EUROSTAT, 2016; Authors' calculation 